\title{
Deployment of Smart City Concept in Poland. Selected Aspects
}

The concept of Smart City is concerned primarily with integration ICT with processes performed in the city. The paper identifies applications and requirements of Smart Cities grouped into two topics: Smart Grid and Smart Tourism and reviews selected projects implemented in these areas in Poland.

Keywords: sustainable development, Smart City, Smart Grid, Smart Tourism.

Sumanaus miesto koncepcija pirmiausia apima informacijos ir telekomunikacijų technologiju integraciją (ICT) su tam tikrais procesais vykstančiais mieste. Šis straipsnis identifikuoja ir aprašo programas ir reikalavimus sumaniam miestui (angl. Smart City), kurias galima suskirstyti ị dvi grupes: sumanaus miesto tinklelio (angl. Smart Grid) ir sumanus turizmo (angl. Smart Tourism). Straipsnio pabaigoje apibendrinami pasirinkti projektai, kurie yra igyvendinami tam tikruose Lenkijos regionuose.

Raktiniai žodžiai: tvarus vystymasis, sumanus miestas, sumanus tinklelis, sumanus turizmas.

\section{Introduction}

Problem of the research. The paper explores the issues of sustainable development concept in the city management. The concept of ubiquitous city or Smart City is associated with a city using new technologies. This city combines elements of its information systems infrastructure and services. ICT is in a center of Smart City model for urban development. The concept is also linked with Smart Grid. There is no one definition of Smart Grid today, it is rather a vision for the electric delivery system of the future that rapidly changes the actual electrical infrastructure into a network of interconnected devices, automated, and interactive as the Internet. The technology must be adapted and configured for each country, region, city and some power distributors. Each city should prepare a suitable vision for Smart Grid that consider how and where to invest in the new grid and communication infrastructure taking under consideration local conditions to benefit in a maximum way. One of the services, not accounted for in the Smart

Beata GONTAR - PhD, adjunct; University of Łódź, Faculty of Management. Address: Matejki Street 22/26. Tel.: 4842 6355045. E-mail: bgontar@wzmail.uni.lodz.pl.

Zbigniew GONTAR - PhD, researcher; University of Łódź, Faculty of Management, academic teacher. Address: Matejki Street 22 / 26. Tel.: 4842 6355045. E-mail: zgontar@wzmail.uni.lodz.pl. 
City definition, is tourism. Smart City should make life easier for residents, but also provide functionality for tourists planning to arrive and stay there. Tourism is one of the industries generating the most revenue (in 2011 Poland was visited by 13.1 million tourists, what increased over in the previous year by $5 \%$ ), and these are used for accelerating the development of the city. Digitization of many spheres of life, the universality of the Internet, multimedia, and mobile devices is changing the face of the city, including the tourism industry. This forces a change in the way of offering travel services.

The object of the research is the Smart City policy and cases relating to energy and tourism management in the city. Different approaches in developing Smart Cities have been examined and various initiatives to develop projects linked to sustainable development of the cities in Poland.

The goal of the research is to identify applications and requirements of Smart Cities grouped into two topics: Smart Grid and Smart Tourism. The paper presents some selected projects implemented in Poland. On the base of analysis, the authors suggest a new strategy for developing Polish cities according to Smart City concept. It is assumed that the strategies will be developed with leading Polish IT companies, universities and Polish consulting firms.

The objectives of the article are as follows:

- to discuss the sustainable development concept as a base of Smart City idea,

- to point out the importance of integration ICT technology with operations in Smart City,

- to review Smart City definitions used by ICT companies,
- to present case studies in the field of Smart Grid and Smart Tourism,

- to outline a roadmap for development of Smart City concept.

Methods of the research, used in the article, include the issue analysis, desktop study (review of academic papers, policy statements, funding programmes, consultancy reports, current projects initiatives), case studies, research questions (how do Smart City initiatives framework is defined, who are the key players in Smart City strategy formation, what Smart Grid and Smart Tourism initiatives are undertaken in Polish Smart Cities) and state of art of deployment situation in selected Polish cities.

Relevance of the research: developing Smart City requires a strategic approach. Analysis of different approaches to the building of a Smart City, and specific projects helped the authors to define the Smart City road map and the necessary artifacts of Smart City.

\section{Sustainable development}

The sustainable development concept assumes that resources that people do use every day for business life and leisure are limited, so they should be used in a way that would preserve the ecosystems in the long term. Meeting the challenges of sustainable development can be achieved through the integration of environmental, economic and social policies.

The sustainable development concept aims at (Batagan, 2011):

- improving quality of life - it is the goal of development,

- living in accordance with the limits of the environment - it is the goal of sustainability, 
ress.

- investing in technological prog-

More than a half of the world's population is already living in urban areas, and that percentage is expected to rise to $75 \%$ by 2050 . The path to sustainable development has to pass through cities. The cities are obliged to organize themselves to advance green growth for all and improve the everyday lives of its residents aggregating different kinds of critical infrastructure and systems enabled by information technology. Some authors say that the goals of sustainable development are the same with the objectives of Smart Cities.

\section{Smart City concept}

"Smart Cities are a new style of city providing sustainable growth and designed to encourage healthy economic activities that reduce the burden on the environment while improving Quality of Life (QoL) such as housing, economy, culture, social and environmental conditions" (Japan Smart City Portal, 2013). Smart City concept is an attempt to answer the following problems: urbanisation, aging of social infrastructure in developed countries, cutting $\mathrm{CO} 2$ emissions.

There are variety of definitions and interpretations of Smart City. The concept of Smart City is concerned primarily with integration of Information \& Communication Technologies (ICT) with processes performed in the city (referring to the urban physical and social infrastructures, including: energy, water, buildings, transportation, communications, administrative services, etc.) with the aim to obtain optimal efficiency of these processes, or additional functions of these processes not possible to achieve without ICT, or monitor security aspects of city through new ways of monitoring, connecting, and analyzing these processes. This integration is a result of strategy, planning, and programs developed for municipal authorities by ICT companies (e.g. Toshiba with the Yokohama Smart City Project - YSCP in Japan, or Ericsson with King Abdullah Economic City project in Saudi Arabia, or Cisco with Connected Urban Development program, and Smart City Framework, and IBM with Smarter Cities Challenge program (How to Transform a City. Lessons from the IBM Smarter Cities Challenge, 2012), Smart Planet concept, Smart Computing model, or Smarter Cities portal (Japan Smart City Portal, 2013)), by academic institutions (Christiansson, 2010), or by consulting firms (e.g. Accenture has developed the Intelligent City Network to assist utilities and cities in deploying Smart Grid solutions, and runs the Global Cities Forum, which works on nearly 100 Smart Grid and Smart City pilot projects). There are also attempts to create global network of industry townships dedicated to Smart City concept (SmartCity Dubai in Saudi Arabia, SmartCity Kochi in India, and SmartCity Kalkara in Malta (Smart City, 2013)), global initiative Smart City Project (encompassing leading companies of the world: e-solutions Inc., ITOCHU Corporation, SAP, NTT Communications, LG CNS Co. Ltd., JX Nippon Oil \& Energy Corporation, Shimizu Corporation, Sharp Corporation, Nikken Sekkei Ltd., Hewlett-Packard Japan, Ltd., Hitachi Ltd., the Future Design Center incorporated association (FDC), Mitsui Fudosan Co. Ltd., Yamatake Corporation) to develop and spread state-of-the-art next generation environmental city (Smart City Project, 2013), Smart Cities Stakeholder Platform (Smart City Project, 2013) 
initiated by the European Commission to identify and spread relevant information on technology solutions and needs required by practitioners, programs created by particular cities (e.g. Amsterdam Smart City - ASC), programs created by government (e.g. Smart Grid, Smart City Australian government funded project, led by Ausgrid (Smart Grid, Smart City, 2013), special support instruments (e.g. "JESSICA - Joint European Support for Sustainable Investment in City Areas" Urban Development Funds), and academic programs (e.g. MIT with Smart City SENSEable lab, and Terreform One projects (Smart City Project, 2013)), Centre of Regional Science at the Vienna University of Technology with European Smart Cities project (European Smart City, 2013). Smart City concept encompasses usually the following areas: smart buildings, smart infrastructures (water, energy, heat, and transportation) and smart services (e-substitutes and e-services for travel, health, education, and entertainment) for city dwellers and travelers. The table 1 presents selected ICT companies' definitions of a Smart City.

\section{Polish cities on the road toward Smart City}

For the first step of the research, on the base of numerous published information authors have identified a list of technical artifacts as determinants of Smart City in the area of Energy Efficiency and Tourism. The authors decided for following items for further study: public hotspots, intelligent transportation systems, renewable energy facilities installed on public properties, advanced metering infrastructure installed, smart street lighting systems, electric (and hybrid) cars charging infrastructure or other initiatives to support that type of transport, Smart City (mobile) web applications and tour guide (mobile) web application. The authors have started research from big Polish cities (most of them are voivodeship's capitals). The data (collected in April and May 2013), concerning these artifacts from selected cities, are summarized in the table 2.

\section{Smart Grid solutions in Polish cities}

An idea of Smart Grid is to change the current power system to more dispersed, combined of all grid elements intelligently connected in order to enhance the overall functionality of the electric power delivery system, to ensure reliability, optimize the use of energy, minimize environmental impact, manage assets and contain costs. There are two main reasons for that. One - the current grid infrastructure is very old and need to be modernized, the second - the energy market is changing and demands new solutions (Pamuła, 2012). In order to achieve better energy efficiency, a wide range of programs can be run by local municipalities:

- changing street light systems, installing Renewable Energy Resources on public buildings,

- implementing intelligent building solutions,

- supporting local energy utilities in new energy demand programs deployment.

The basic element that allows energy customers to easy control energy usage is the Advanced Metering Infrastructure (AMI). Then new smart energy technology relayed on ICT helps citizens to save 
ICT companies' definitions of a Smart City

Table 1

\begin{tabular}{|c|c|}
\hline Accenture & $\begin{array}{l}\text { An intelligent or Smart City is one that meets its challenges through the strategic application } \\
\text { of ICTs to provide more efficient, new or enhanced services to citizens or to manage and } \\
\text { optimize its existing infrastructure and plan for new more effectively and helps create and } \\
\text { attract new industries to their areas, and monitor and track government's progress toward } \\
\text { policy outcomes, including meeting climate change mitigation and adaptation goals. (Webb, } \\
\text { et al., 2011). }\end{array}$ \\
\hline Toshiba & $\begin{array}{l}\text { A smart community is a next generation community in which the management and opti- } \\
\text { mized control of various infrastructures such as electricity, water, transportation, logistics, } \\
\text { medicine, and information are integrated. The aspects of a perfect Smart City encompasses: } \\
\text { more ecology (reduce CO2 and energy consumption, introducing renewable energy systems, } \\
\text { EV Systems), better quality of energy (maintain stability of energy), better quality of life } \\
\text { (IT healthcare systems, LED monitor and lamp), better economy (energy efficiency), others } \\
\text { (water, environment). }\end{array}$ \\
\hline IBM & $\begin{array}{l}\text { A Smart City is instrumented (sourcing of real-time real-world data from both physical and } \\
\text { virtual sensors, interconnected across multiple processes, systems, organizations, industries, } \\
\text { or value chains), interconnected, intelligent. Two main elements of Smart City: Intelligent } \\
\text { Operations Center, and Smart Computing Model. } \\
\text { Intelligent Operations Center for Smarter Cities provides an executive dashboard to help city } \\
\text { leaders gain insight into all aspects of the city. The executive dashboard spans agencies and } \\
\text { enables drill-down capability into each underlying agency such as emergency management, } \\
\text { public safety, social services, transportation, or water. Intelligent Operations Center allows } \\
\text { city leaders to: leverage information across all city agencies and departments to make smarter } \\
\text { decisions, anticipate problems to minimize the impact of disruptions to city services and } \\
\text { operations, coordinate cross-agency resources to respond to issues rapidly and effectively. In- } \\
\text { telligent Operations Center is designed to: monitor agency and citywide operations, involve } \\
\text { citizens and businesses in incident reporting and resolution, gather and analyze citizen feed- } \\
\text { back using social media, manage a broad range of government and commercial operations, } \\
\text { deploy rapidly with minimal IT resources. IBM Smart Computing Model refers to Big Data, } \\
\text { Cloud, and Optimized Systems. }\end{array}$ \\
\hline CISCO & $\begin{array}{l}\text { CISCO proposes a framework (Falconer, Mitchell, 2012) for how to define and assess Smart } \\
\text { City initiatives. The CISCO's Smart City is strongly connected to the role of networking and } \\
\text { internet based services in driving changes of reduction of carbon emissions, delivering in- } \\
\text { novative, sustainable models for urban planning and economic development (Hodgkinsonn, } \\
\text { 2011). }\end{array}$ \\
\hline Siemens & $\begin{array}{l}\text { Siemens runs the Green City Index, which measures and ranks the environmental perfor- } \\
\text { mance of cities from around the world. } \\
\text { - Pull factors: economic opportunities, better living environment, education opportunities, } \\
\text { well-being, vibrancy; } \\
\text { - Ppush factors: pollution, congestion, crime/personal safety, lack of well-being, } \\
\text { discrimination. }\end{array}$ \\
\hline
\end{tabular}

energy from one side and help the utilities to secure supply energy from the other (for example in efficient detection of power system failures and removal of energy losses).

EU requires all Members States to implement AMI for end users by the end of year 2020. The governments have to decide how it should be done (the scope and schedule) depending on cost/benefits analysis of pilot installations. Polish power utilities have started this type of installations a few years ago. According to the results listed in table 2 , some 
Smart Cities artifacts identified in selected Polish cities

Table 2

\begin{tabular}{|c|c|c|c|c|c|c|c|c|c|}
\hline City & $\begin{array}{l}\text { Population / } \\
\text { Tourists per } \\
\text { year (2011) }\end{array}$ & $\begin{array}{l}\text { Num- } \\
\text { ber of } \\
\text { public } \\
\text { hot- } \\
\text { spots }\end{array}$ & $\begin{array}{c}\text { Intel- } \\
\text { ligent } \\
\text { trans- } \\
\text { por- } \\
\text { tation } \\
\text { systems }\end{array}$ & $\begin{array}{l}\text { RES } \\
\text { facili- } \\
\text { ties on } \\
\text { public } \\
\text { proper- } \\
\text { ties }\end{array}$ & AMI & $\begin{array}{c}\text { Smart } \\
\text { street } \\
\text { light- } \\
\text { ing }\end{array}$ & $\begin{array}{c}\text { Smart } \\
\text { City } \\
\text { (mobile) } \\
\text { web ap- } \\
\text { plica- } \\
\text { tions }\end{array}$ & $\begin{array}{c}\text { El.cars } \\
\text { charging } \\
\text { infra- } \\
\text { structure } \\
\text { \& parking }\end{array}$ & 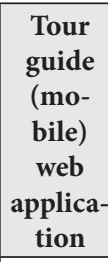 \\
\hline Białystok & \begin{tabular}{|l}
$294.298 /$ \\
29.305
\end{tabular} & 8 & $\mathrm{Y}$ & $\mathrm{Y}$ & $\begin{array}{l}\text { pilot } \\
2013\end{array}$ & N/A & $\mathrm{Y}$ & N/A & $\mathrm{Y}$ \\
\hline $\begin{array}{l}\text { Bielsko - } \\
\text { Biała }\end{array}$ & $174.503 / \mathrm{N} / \mathrm{A}$ & N/A & $\mathrm{Y}$ & $\mathrm{Y}$ & $\mathrm{N} / \mathrm{A}$ & N/A & $\mathrm{N}$ & N/A & $\mathrm{N}$ \\
\hline Bydgoszcz & $170.847 / \mathrm{N} / \mathrm{A}$ & 5 & $\mathrm{~N}$ & $\mathrm{Y}$ & $\mathrm{N} / \mathrm{A}$ & N/A & $\mathrm{Y}$ & N/A & $\mathrm{Y}$ \\
\hline Gdańsk & \begin{tabular}{|l|}
$460.517 /$ \\
6.300 .000 \\
\end{tabular} & 72 & $\mathrm{Y}$ & $\mathrm{Y}$ & $\mathrm{N} / \mathrm{A}$ & pilot & $\mathrm{Y}$ & N/A & $\mathrm{Y}$ \\
\hline Katowice & $308.269 / \mathrm{N} / \mathrm{A}$ & 50 & $\mathrm{Y}$ & $\mathrm{Y}$ & $\mathrm{N} / \mathrm{A}$ & N/A & $\mathrm{Y}$ & $\begin{array}{c}\text { free } \\
\text { parking }\end{array}$ & $\mathrm{N}$ \\
\hline Kielce & $201.815 / \mathrm{N} / \mathrm{A}$ & 30 & $\mathrm{~N}$ & $\mathrm{~N}$ & $\mathrm{~N} / \mathrm{A}$ & N/A & $\mathrm{N}$ & $\mathrm{N} / \mathrm{A}$ & $\mathrm{N}$ \\
\hline Kraków & \begin{tabular}{|l|}
$759.137 /$ \\
8.645 .000 \\
\end{tabular} & 100 & $\mathrm{~N} / \mathrm{A}$ & N/A & $\mathrm{N} / \mathrm{A}$ & pilot & $\mathrm{Y}$ & $\begin{array}{c}Y+\text { (low } \\
\text { fee) }\end{array}$ & $\mathrm{Y}$ \\
\hline Lublin & $348.567 / \mathrm{N} / \mathrm{A}$ & 19 & $\begin{array}{l}\text { plan } \\
2014 \\
\end{array}$ & $\mathrm{Y}$ & $\mathrm{N} / \mathrm{A}$ & N/A & $\mathrm{N}$ & N/A & $\mathrm{N}$ \\
\hline Olsztyn & $175.420 / \mathrm{N} / \mathrm{A}$ & 4 & plan & $\mathrm{N}$ & $\mathrm{N} / \mathrm{A}$ & pilot & $\mathrm{N}$ & N/A & $\mathrm{N}$ \\
\hline Poznań & \begin{tabular}{|l|l|}
$553.564 /$ \\
523.000 \\
\end{tabular} & 24 & $\mathrm{Y}$ & $\mathrm{Y}$ & $\mathrm{N} / \mathrm{A}$ & pilot & $\mathrm{Y}$ & N/A & $\mathrm{Y}$ \\
\hline Rzeszów & \begin{tabular}{|l|l}
$180.031 /$ \\
115.344
\end{tabular} & 12 & $\mathrm{~N}$ & $\mathrm{Y}$ & $\mathrm{N} / \mathrm{A}$ & N/A & $\mathrm{N}$ & N/A & $\mathrm{N}$ \\
\hline Szczecin & \begin{tabular}{|l|l|}
$194.850 /$ \\
401.700 \\
\end{tabular} & 140 & $\mathrm{Y}$ & $\mathrm{Y}$ & pilot & N/A & $\mathrm{Y}$ & low fee & $\mathrm{Y}$ \\
\hline Toruń & \begin{tabular}{|l|}
$204.921 /$ \\
$1.630 . .000$
\end{tabular} & $2 / 17$ & plan & $\mathrm{Y}$ & N/A & $\begin{array}{l}\text { plan } \\
2013\end{array}$ & $\mathrm{~N}$ & N/A & $\mathrm{Y}$ \\
\hline Warszawa & \begin{tabular}{|l|}
$783.817 /$ \\
11.520 .000 \\
\end{tabular} & 150 & $\mathrm{~N} / \mathrm{A}$ & $\mathrm{Y}$ & $\begin{array}{l}\text { pilot } \\
2012 \\
\end{array}$ & pilot & $\mathrm{Y}$ & $\mathrm{Y}$ & $\mathrm{Y}$ \\
\hline Wrocław & \begin{tabular}{|l|}
$294.569 /$ \\
753.268 \\
\end{tabular} & 69 & $\mathrm{Y}$ & $\mathrm{Y}$ & $\mathrm{N} / \mathrm{A}$ & N/A & $\mathrm{Y}$ & $\mathrm{Y}$ & $\mathrm{Y}$ \\
\hline $\begin{array}{l}\text { Zielona } \\
\text { Góra }\end{array}$ & $117.699 / \mathrm{N} / \mathrm{A}$ & 14 & $\mathrm{~N}$ & $\mathrm{Y}$ & N/A & N/A & $\mathrm{N}$ & $\mathrm{Y}$ & $\mathrm{N}$ \\
\hline Zakopane & \begin{tabular}{|l|}
$26.09 /$ \\
3.000 .000 \\
\end{tabular} & N/A & $\mathrm{Y}$ & $\mathrm{Y}$ & N/A & N/A & $\mathrm{Y}$ & N/A & $\mathrm{N}$ \\
\hline Łódź & \begin{tabular}{|l|}
$329.848 /$ \\
780.000
\end{tabular} & 20 & $\mathrm{Y}$ & $\mathrm{Y}$ & $\begin{array}{l}\text { pilot } \\
2013\end{array}$ & N/A & $\mathrm{Y}$ & $\mathrm{Y}$ & $\mathrm{Y}$ \\
\hline
\end{tabular}

Sources: based on authors own research.

Polish cities are at the stage of preparing pilot installations, some passed it and some still waiting for the distributor's decisions to begin the process. The other projects leading to Smart Grid are at the similar stage. 
Polish municipal governments search for the way to be more environment friendly and to cut energy cost at the same time. A big number of Polish cities decided to install RES on public buildings (schools, sport and recreation facilities, hospitals, nursery houses), change local street lighting system starting pilot LED light installations, improve building thermo isolation. Some decided to support the idea of PV and hybrid cars by running the programs of no (or very low) parking fee in the center of the city or preparing special public charging infrastructure. Only a few cities have prepared some type of Strategic Energy Plan or Activity Plan for the Energy.

The most advanced in the way toward Smart City regarding energy efficiency is Bielsko-Biała. According to energy management programs the city has established a special Office for Energy in 1997 and started to run several programs. One of the first was to monitor the local public buildings (including schools) energy costs. This one helped to find the influence of thermal insulation of the building and prepare modernization programs for the others public properties. The big project to change the districts heating system was established and several RES were installed on public buildings to supply energy (ex. PV panels on public nursing home and school). The city has Strategic Plan, which is a document leading the city towards for sustainable energy, describing general targets and resources to achieve them as well as giving some proposals for action in more detailed manner. Today the city is monitoring the energy consumption of 140 municipal properties and information system, analyzes their energy consumption. In the future, information will be collected through AMI connected to a broadband network and the database will be connected digital city map. The city joined Energy Cities European Association and Convent for Mayor known as "Energy for Mayors" (an initiative involving European cities and towns in efforts to protect the climate and exceed the goals of the EU climate and energy policy established in 2020) association and plays active role in it.

Polish smaller cities are in some cases more advanced in Smart Grid projects then Voivodeship's Capitals. A lot of them install RES on public buildings like schools welfare center, sport centers and other places. Kalisz is the first Polish city with the intelligent street lighting infrastructure. It is also the first Polish city, where all residential customers are equipped with intelligent meters and a place where the Energa (Polish Energy Distribution System Operator) together with the Polish Energy Transmission System Operator are going to test new active demand programs (starting in 2013). About 1700 residential customers will take part in the pilot program to test new possibilities of Demand Side Management programs like Time-of-use tariffs, Critical Peak Pricing. The result will help to improve the future offers for the residential customers sector. The pilot is design to find the customers ability to change their energy behavior, and to find the most effective incentives. Pilot participants will be offered an access to a new information system providing real time data on energy usage and related costs accessible through web page and mobile applications.

As the cities are also the target of the touristic or business trips some new ideas of smart solutions are introduced. PURO Hotel is a new chain of intelligent hotels in Poland. The idea of the PURO smart 
hotels is to shorten service time of visitors. Using the Internet or mobile phone visitors will be able to book a room quickly and independently, check in and check out of the hotel. Reservation will be possible through online booking system or in the hotel reservation using the control panel. A traditional reception do not exist, as simplify and shorten procedures make the hotel an almost self-service. In the hotel rooms a central touch screen to control the air conditioning, and the color and intensity of LED lighting are installed. Guests will enjoy access to wireless broadband internet access and free international calls. Through a special console located next to the bed, guests will have the opportunity to connect electronic devices (laptops, mp3 or iPhone) to 40 inch TV (www.purohotel.pl). The first hotel is PURO Hotel Wrocław, next are planned in Kraków and Warszawa. By the end of 2015 Norwegian holding company is going to build 8 hotels.

\section{E-tourism and cultural information}

Among different initiatives which are a part of Smart City projects there are education and culture (Gontar, Papińska-Kacperek, 2012), what encompass: e-learning and teleworking, e-tourism and cultural information, e-commerce, etc. Below there are some solutions and projects in the field of e-tourism run in Poland.

Projects of ICT solutions. One of examples of projects run in tourism is ISPEED supported by the city of Warszawa (I SPEED - Information Society Policies for Sustainable European Economic Development, 2013). The project was initiated in 2008, when Poland was preparing for celebrating the Chopin 2010 Year. It was set up to organize special programmes celebration for the 200th anniversary of the greatest Polish composer's birth. Concerning use and development of ICT solutions, project included:

- development of the Royal Route, including Chopin's multimedia benches at key locations with his life playing music and downloadable files for mobiles,

- creating interactive Museum of Chopin, with audio files (like: Chopin's letters), and interactive games etc.,

- development of a Museum's Night Facebook page,

- development of interactive games, downloadable for mobiles.

Concerning the use of different tools and project described above, the results were as follows:

- Museum of Chopin was visited by 175.000 visitors (since April 2010 till February 2011);

- Audio guides were downloaded from city web site over 158.000 times in 6 languages;

- Chopin's mobile application was downloaded more than 160.000 times;

- Mobile Travel Guide was downloaded about 160.000 times (in 2010). It can be estimated that in 2010, Warszawa was visited by $7.85 \mathrm{mln}$ visitors (including $2.62 \mathrm{mln}$ foreigners).

QR codes. "Decode Lódź" was the first and the most famous action promoting the city using QR codes. Matrix barcodes are two-dimensional barcodes (2D), which provide fast access to web resources for mobile phone users. The main idea of the project was to help foreign tourists to have access to tourists' tours in the city any time in some languages. QRcodes were placed on the important buildings (places) in Łódź and allow visitors to get information about them and history 
of the city (www.odkodujlodz.pl, kreatywna.lodz.pl). Lately there is a new project which is a kind of mobile tourist guide. Along main streets there were placed 150 boards with matrix barcode which lead to information about monuments, their history, or geographical location. Tourist can choose one from 3 language versions (Polish, German or English). Lector is additionally available. This mobile guide is a part of bigger project - "Through Żory to Sląsk - creation of e-tourist information system" fund by EU (Przez Żory na Śląsk, 2013).

In Warszawa, tourist trials use two types of codes: (1) QR code and (2) Data Matrix. Matrix barcodes were located on the "Traces of Chopin" and it was also a part of I-SPEED project. There are fifteen multimedia benches located on the route. Everybody can read matrix barcodes using mobile phones with built-in digital cameras and equipped with the right software. Visitors can get the software downloading on their phone directly from the Internet. User without installed application, has to send an SMS with text "FOTOKODY" and send it to the free number - 8085. After a while, the message is received with a link to the needed application. Then, the application should be launched and the photo of selected code should be taken by a phone. In the code there is a link to the mobile travel guide with the information about Chopin. It can be composer biography, information on tourist Trail and also Frederic Chopin footsteps in Warszawa. The application can be also directly available on mobile devices from the internet (Chopin 2010, 2013).

City Guide. City guide is a free mobile application, where one can find actual information about coming events, local monuments and interesting places worth to see. Most of the big cities in Poland offer tourists mobile applications. One of the city guides available for tourists is Wrocław City Guide. There are for example: tourist routes, both walking and cycling, museums, monuments, places for children, pubs, restaurants, parks, public transport and possibilities of different connections, and all of that on the maps. The official version available on Android and iOS. All the data for guide are taken from the database of city portal (www.wroclaw.pl). The guide is accessible in two language versions: Polish and English. All events that are in database can be saved in special planner. The mobile guide works also offline. Its attitude is a use of geolocalisation - user's GPS. Thereby can adapting the displayed information to user's localization.

Mobile Timetable. Since 1 October, 2007 it is possible to download in Tychy the timetable to mobile device. The timetable works offline. It is installed once ( 2 files, $40 \mathrm{~Kb}$ ) and it is accessible anytime. The application which let to download the mobile timetable is called Ginger. People who do not see well and use mobile phones with system Symbian (Series 60) can use GingerBlu application, which is enrich in lector voice to read all messages. It allow to choose the line, direction, bus stop (Ginger - rozkład w komórce, 2013); (Mobilny przewodnik miejski, 2013).

Virtual Museum. There are some projects on virtual museums in Poland. One of them concerns Virtual Museums of Malopolska (2007-2013) - a platform which will collect around 700 digitized exhibits from 35 museums of the region. During the project, museums will select over 900 exhibits, and only 500 will be chosen. They will be digitized in 3D technology that delivers realistic color and 
a sharper image, and 200 of them in 2D technology. Visitors will be able to find there not only exhibits, articles but also what is quite new concerning Polish virtual museums - a game. To link the education with presentation of portal exhibits, the idea of gamefication was used. To game one has to look carefully for information and get knowledge to solve tasks. So the main aim of the game is to know better the collections of the virtual museum (Wirtualne Muzea Małopolski, 2013).

\section{Roadmap framework}

The aim of presented below Smart City roadmap framework is to propose new vision of strategy to introduce Smart City concept in Polish cities. The framework focuses on the following three main steps:

1) Refining the strategic goals of the city so as to make the city more economically competitive (developing the strategy in cooperation with ICT company, academic institution, or consulting company).

The city of Katowice is close to achieve this goal. The City Hall of Katowice in cooperation with IBM implemented in 2010 an IBM Executive Service Corps (ESC) project. The aim of the project was to identify crucial problems in the City and the Silesia Metropolis and to prepare strategy for the city how to achieve sustainability goals (to become smarter). The key factors in the area of economy, environment and social issues, and its complex nature were identified. The project did not focus on single matters like building a new bridge, road or traffic monitoring, but analyzed a city as a pattern of interconnections with a health care, water balance, transport and energy systems. The project identified the following five areas of opportunity (Smarter City Challenge, 2013):

- marketing the value proposition of the Katowice and Upper Silesia regions,

- optimizing transportation services within the city/region to make them more effective for residents and businesses,

- more fully aligning key government, industry, academic and finance sectors to drive economic development, innovation, job creation, and population gains,

- involving citizens and businesses more fully in the planning Government processes,

- addressing quality of life issues as a way of retaining young talent.

and identified the three following points of development (Smarter City Challenge, 2013):

- the City of Commerce and Culture: How can the city's economic development and marketing strategy be strengthened to improve quality of life (economic and social) and attract increased investment,

- the Well Planned City: How can key public infrastructures - especially in the areas of transportation and public safety - be planned and developed to best support the needs of the city/region,

- the City of Digital Innovation: How can communication and collaboration between key parties be improved to support the continued development of community, as well as the deeper partnerships needed for long term success.

2) Establishing competency center (Gontar, 2012).

Smart City concept is strongly connected with measuring, monitoring, modeling and management activities. IBM 
proposes the two following solutions: the Intelligent Operations Center (IOC) for Smart Cities, and the Integrated Information Core (IIC). According to Gartner Inc., such Intelligent Computing is implemented through competency centers equipped with decision support systems. In Poland, IBM proposes courses IBM Intelligent Operations Center Programming Model Fundamentals.

3) Establishing innovation cluster.

Smart City concept is based on the innovative ICT-based services of disruptive character, which makes it necessary to attract $\mathrm{R} \& \mathrm{D}$ investment. The most recent form of city's support for innovation is innovation cluster. In Poland, there is one outstanding initiative in this area, namely Green Stream Project (Energetyczne technologie jutra, 2013), in which Warszawa, Kraków, Gdańsk, and Katowice cooperate. These cities are thereby on the track to create the network of Smart Cities.

\section{Conclusions}

It is the role of local governance to push the city on the road to become smart. It is not enough to follow the standard tasks, it is the time to find funds and invest in new technology and solutions, for those attractive business solutions should be prepared. The good business-municipality-science relation is the basic factor of success of Smart City projects. The second one is to identify a variety of transparent sources of funding. Some of Smart Grid solutions in Poland are supported by EU funds. As authors propose in the roadmap presented above, the city should start from the vision, then establish relevant municipal structures (competency centers) and finally invest in the sense of attract investors to establish innovation clusters relating to the Smart City technologies.

On the base of conducted researches, the Aauthors conclude that there are no Smart Cities in Poland. The Authors identified interesting cases of separated initiatives, which can be a seed idea - a beginning of smart conception in the city. As it can be concluded from table 2 Polish cities are at the very beginning stage of preparing intelligent solutions in the area of Energy Management. In most cases the implementation covers only small pilot installation (like a few streets with intelligent lighting systems, one or two cross roads and lines with intelligent transport system, limited number of touristic routes - audio guides - accessible by mobile phone). Even at this stage some differences between the levels of investments done can be observed. But, the authors have to admit that the number of the solution is growing each year, especially concerning tourism. The reason is costs of implemented solutions.

The presented study is the entrance step to wider researches of cities activities in that area. The Authors plan to take a closer look for cities activity plan and search for detailed information of planned projects and their results. The study is expected to lead to establish a type of city smart coefficient describing the level on road of becoming smart in comparison to an average and (or) model city. 


\section{References}

1. Batagan, L. (2011). Smart Cities and Sustainability Models, Informatica Economică. Vol. 15, no. 3/2011, ISSN 1453-1305, pp. 80-87.

2. Chopin 2010. (2013). Internet access: <wap. looksoft.pl/chopin/>, [accessed: May 13, 2013].

3. Christiansson, M. (2010). Improving business processes and delivering better e-services. A guide for municipalities from Smart Cities. Karlstad University and the municipality of Karlstad in Sweden. doi: http://www.rcc.gov. pt/SiteCollectionDocuments/Improving $\% 20$ Bus iness $\% 20$ Processes $\% 20$ a n d $\% 20$ Delivering\%20Better\%20E-Ser\%20vices\%20 -\%20Smart\%20Cities.pdf.

4. European Smart City. (2013). Internet access: http://www.smart-cities.eu/, [accessed: May 12, 2013].

5. Energetyczne technologie jutra. (2013). Internet access: http://start.greenpl.org/, [accessed: May 13, 2013].

6. Falconer, G., Mitchell, S. (2012). Smart City Framework. A Systematic Process for Enabling Smart + Connected Communities. Cisco Internet Business Solutions Group (IBSG).

7. Ginger - rozkład w komórce. (2013). Internet access: <http://www.mzk.pl/rozklad-jazdy-mzkw-telefonie-komorkowym/>, [accessed: May $15,2013]$.

8. Gontar, B., Papińska-Kacperek, J. (2012). E-turystyka jako element koncepcji budowania inteligentnego miasta, Zeszyty Naukowe Uniwersytetu Szczecińskiego nr 721, Folia Informatica nr 29, Szczecin 2012, ISSN 1640-6818, pp. 189-201.

9. Gontar, Z. (2012). Centrum usług wspólnych a wdrażanie systemów Smart Grid Analytics, Budownictwo i inżynieria środowiska, Zeszyty Naukowe Politechniki Rzeszowskiej, ISSN 02092646, t.1, pp. 257-264.

10. Hodgkinsonn, S. (2011). Is Your City Smart Enough? Digitally enabled cities and societies will enhance economic, social, and environmental sustainability in the urban century. Ovum Consulting.
11. How to Transform a City. Lessons from the IBM Smarter Cities Challenge. (2012). IBM Smart Cities White Paper. IBM Institute for Business Value. IBM Corporation.

12. I SPEED - Information Society Policies for Sustainable European Economic Development. (2013). Internet access: http://www.ispeed.eu/, [accessed: May 15, 2013].

13. Japan Smart City Portal. (2013). Internet access: < jscp.nepc.or.jp>, [accessed: May 12, 2013].

14. Mobilny przewodnik miejski. (2013). Internet access: <http://www.mzk.pl/mobilny-przewodnik-miejski/?lang=en $>$, [accessed: May 12, 2013].

15. Pamuła, A. (2012). Usługi DSM w inteligentnych sieciach elektroenergetycznych, w: Zeszyty Naukowe Uniwersytetu Szczecińskiego Ekonomiczne Problemy Usług, Wydawnictwo Naukowe Uniwersytetu Szczecińskiego, ISSN 1640-6818.

16. PrzezŻorynaŚląsk. (2013).Internetaccess:http:// www.zory.pl/przez-zory-na-slask-stworzeniesystemu-e-informacji-turystycznej,new, 0 . html,108, [accessed: May 13, 2013].

17. Smart City. (2013). Internet access: <http://www. smartcity.ae/>, [accessed: May 12, 2013].

18. Smarter City Challenge. (2013). Internet access:< http://smartercitieschallenge.org/city_katowice_poland.html>, [accessed: May 12, 2013].

19. Smart City Project. (2013). Internet access: http://www.smartcity-planning.co.jp/en/index. html, [accessed: May 12, 2013].

20. Smart Cities Seoul: a case study. (2013). ITU-T Technology Watch Report. ITU-T.

21. Smart Grid Smart City. (2013). Internet access: http://www.smartgridsmartcity.com.au/, [accessed: May 12, 2013].

22. Webb, M., Buscher, V., Giles, S., Mulligan, C. (2011). Information Marketplaces The New Economics of Cities. The Climate Group, ARUP, Accenture and The University of Nottingham.

23. Wirtualne Muzea Małopolski. (2013). Internet access: http://blog.muzea.malopolska.pl/, [accessed: May 11, 2013].

The paper submitted: May 15, 2013

Prepared for publication: September 19, 2013 


\section{Beata GONTAR, Zbigniew GONTAR, Anna PAMUŁA}

\section{SUMANAUS MIESTO KONCEPCIJOS VYSTYMAS LENKIJOJE. PASIRINKTAIS ASPEKTAIS}

\section{S a n t r a u k a}

Tvaraus vystymosi sąvoka reiškia, kad ištekliai, kuriuos žmonès naudoja kiekvieną diena organizuodami verslą ir laisvalaiki, yra riboti, todèl jie turètų būti naudojami taip, kad būtų išlaikomas ekosistemų funkcionavimas ilgu laikotarpiu. Šie darnaus vystymosi tikslai gali būti pasiekti užtikrinant aplinkosauginès, ekonominès ir socialinès politikos integraciją.

Europos Sąjungos teisès aktai siekia, kad naujoji tvarka būtų igyvendinama visose sąjungos valstybèse. Valstybès, norėdamos išvengti sankcijų, turi užtikrinti, kad miestai atitiktų ES keliamus reikalavimus ir pradètų investuoti ị energijos kaštų, CO2 emisijos, atliekų ir nuotekų mažinimą. Kitaip sakant, turi būti sukurtas pažangus miestas (angl. Smart City). Sumanaus miesto sąvoka asocijuojasi su šiuolaikinio miesto, naudojančio naująsias technologijas, sąvoka - ITC technologijų naudojimas, kuriomis siekiama palengvinti šalies gyventojų gyvenimą. Toks miestas apjungia informacijos sistemų, infrastruktūros elementus ir paslaugas kaip energetika, švietimas, sveikatos apsauga, visuomeninè apsauga ir transportavimas. ICT yra sumanaus miesto modelio pagrindas miestų plètrai.

Ši sąvoka yra glaudžiai susijusi su protingo tinklelio (angl. Smart Grid) sąvoka. Nèra nei vieno konkretaus protingo tinklelio apibrèžimo šiandien. Greičiau tik vizija, kurios pagrindas ateities elektros sistemų pristatymas, kurios greitai keičia elektros kaupimo infrastruktūrą i sujungtų prietaisų tinklą, kuris yra automatizuotas ir interaktyvus kaip internetas. Tai technologija, kuri nèra tinkama visiems, o turi būti pritaikyta ir sukonfigūruota kiekvienai šaliai, regionui, miestui ar elektros energijos platintojui individualiai. Kelių Žemèlapio (angl. Road Map) tikslas yra parodyti aiškų būdą kaip pasiekti naudos iš tokių protingų tinklelių konkrečioje aplinkoje. Kiekvienas miestas turi parengti tinkamą viziją protingam tinkleliui, kuris apsvarstytų kaip ir kur turi būti investuojama ì naujų tinklų ir komunikacijų infrastruktūrą, atsižvelgiant ị esamas aplinkos sąlygas, kad būtų maksimizuota nauda.

Viena iš paslaugų, kuri nèra ịtraukta ị sumanaus miesto apibrèžimą yra turizmas. Sumanus miestas ne tik turi padaryti lengvesni gyvenimą vietiniams gyventojams, bet taip pat užtikrinti funkcionalumą turistams, kurie planuoja atvykti ir apsistoti šiame mieste. Turizmas yra viena iš pramonės šakų, kuri sukuria didžiausią pelną (Lenkijoje 2011 metais apsilankè 13,1 milijonas turistų, o tai yra $5 \%$ daugiau nei prieš metus), kuris yra naudojamas spartinant miesto plètrą. Daugelio gyvenimo sričių skaitmenizacija, interneto universalumas, multimedija ir mobilieji įrenginiai keičia miesto įvaizdị, ịskaitant ir turizmo sferą. Tai įšaukia pokyčius kelionių organizavimo paslaugose.

Šis straipsnis identifikuoja programas ir reikalavimus sumaniam miestui, kuriuos galima suskirstyti ị dvi temas: sumanaus miesto tinklelis ir sumanus turizmas. Straipsnyje apžvelgiami pasirinkti projektai, kurie buvo igyvendinti Lenkijoje. Remiantis atlikta analize autoriai pasiūlo naują strategiją, kuria būtų perorganizuoti Lenkijos miestai remiantis sumanaus miesto koncepcija. Daroma prielaida, kad strategijos bus igyvendintos kartu su stipriausiomis Lenkijos IT kompanijomis, universitetais ir Lenkijos konsultacinėmis įmonėmis. Strategiją sudaro trys etapai: strateginių tikslų, kurių pagrindas padaryti miestą ekonomiškai konkurencingesnị (igyvendinant strategiją su ICT kompanijomis, akademinèmis institucijomis ar konsultacinemis įmonèmis) apibrèžimas; sukurti kompetencijų centrą; ir sukurti inovacijų klasterị primenančių Žaliojo Garo (Green Stream) iniciatyvas sukurtas Varšuvoje 2007 metais, siekiant sukurti tvarią plètrą Lenkijoje, iskaitant: ekologiškus automobilius, protingas IT ir žaliąją energetiką.

Šio straipsnio tikslas: aptarti tvaraus vystymosi koncepciją, kaip sumanaus miesto pagrindą, išskirti ICT technologijų integracijos, su sumaniam mieste vykstančiais procesais, svarbą, apibrěžti sumanaus miesto koncepciją, kurią naudoja ICT kompanijos, pristatyti sumanaus tinklelio ir sumanaus turizmo atvejų analizes. Tyrimo metodai, kurie naudojami šiame straipsnyje apima problemų analizę, literatūros apžvalgą (mokslinių straipsnių, politinių dokumentų, finansavimo programų, ataskaitų ir esamų projektų), atvejų analizę. Straipsnyje siekiama atsakyti ị šiuos klausimus: kaip sumanaus miesto iniciatyvos yra apibrèžiamos, kas yra pagrindiniai žaidejai sumanaus miesto strategijos kūrime, kokios sumanaus tinklelio ir sumanaus turizmo iniciatyvos yra igyvendinamos Lenkijos sumaniuose miestuose. 